\title{
〔第43回総会シンポジウム〕
}

\section{PACS と規格}

\author{
喜 多 紘一
}

侏)東芝 那須工場

Key words: PACS, ACR-NEMA, MIPS, OSI, NETWORK

\section{STANDARDIZATION FOR PACS}

\author{
KOUICHI KITA \\ Nasu Works, Toshiba Corporation
}

\begin{abstract}
Summary
It is imporant for stimulating PACS markets that a standardization of the interfaces for each component of PACS are carried out so that venders can install own components on an individual basis.

For on-line interfaces between imaging equipment, the ACR-MEMA standards were proposed in the United States and the MIPS standards will be proposed this year in Japan. These standards have the same seven step hierarchy as the OSI referrence model. The presentation layer is specialized for medical imaging use. The physical layer has a 50-pin connector with a 16-bit parallel signal transmission protocol. Communication protocols are very complex system. However, it is important for PACS designers to understand it so they can estimate bounderly condition of each component.

Regarding the magnetic tape standards the JAMIC, MIPS and ACR-NEMA formats are available. The JAMIC format has actually been installed in several types of medical equipment. These formats may be selected according to the specifications of the system when it is difficult to use on-line interfaces.

Standardization is only one step in constructing a multi-vender system. There are many differences between equipment of different venders. Methods of connect with RIS or HIS and abilities how fast or how often the equipment can transmit image data are different. For constructing a multi-vendor system, it is important to appoint a responsible system designer who can propose such specifications to the vendors of the components.

\section{1.はじめに}

PACS のメリット・デメリットが色々議論されてい る.PACSがもっている従来のフィルム保管方式に比較 して本質的に異なる機能は次の 3 点である.1）劣化の ないコピーができること．2）離れた場所へ速く転送で きること．3）転送されたデー夕は返却の必要がなく自 由に加工できること.

したがってこうしたフィルムで実現できないメリット

を強調したシステムから導入が始まると思われる。

PACS は現在，その第一歩としてのパイロットシステ ムがやっと稼動した状態である.ここ10年で, 病院内で 部分的に適用されるパーシャル PACS が定着し, 全病院 を対象とした本格的システムは，その $5 \sim 6$ 年後すなわ ち21世紀をむかえてからと思われる。

その理由は現状の技術では PACS の理想である「いつ でも，どこでも，すぐに，好きなかたちで画像が見られ ること」を実現するには無理があるからである。しかし，


ICメモリー, 磁気ディスク, 光ディスクの容量の増大, 速度の向上おょび価格の低下は急激でかならず, PACS の要求性能は実現されると思われる.

その時をふまえて, 現在はシステム的な試行を進める べき時期にきている．また一部機能を限定すれば現状技 術でも実用的に使用可能なシステムもある。その際，マ ルチベンダのシステムを構築するためには，標準化すな わち規格化が重要である。

ここでは主に，画像通信規格と磁気テープフォーマッ ト規格の現状動向について言及する，画像通信規格につ いては，世の中一般の OA 用機器の通信では OSI がさわ がれているので, OSIの通信のプロトコルとは何かを理 解していただくためにその通信プロトコルについて詳細 に述べる。

光ディスクは，記録方式の標準化が進んでいるものの ディスクとして，メーカ間の互換性はまだない．医用機 器としてこのフォーマットの統一は今後の課題であるが, 現状では規格化の動きがまだ見られないのでここではふ れていない.

\section{2. 通信機能の階層化}

画像機器の間で画像を送受信するためには, お互いに 通信の手順をきめておかなくてはならない。この手順の ことをプロトコルと呼んでいる。

通信のプロトコルとして話題となっているものは，大 型計算機同志の通信プロトコルである. IBM その他の日 本のメーカ同志の計算機が扔互いに接続し，情報交換を 行うために，通信プロトコルの標準化が考えられている。

通信プロトコルの標準化として, ISO (inter national organization for standardization) $の$ OSI (open systems interconnection：開放型システム間相互接続）が 注目を集めている。これは通信プロトコルの基本的考え 方を示しているので, 通信規格の標準化を理解する上で 重要である。

OSI では通信の機能を 7 つ分類し，通信をモデル化 している.これをISO-OSI 参照モデルと言っている. 通 信プロトコルの基本機能を理解するために重要であるの で若干の説明を加える。

OSI では各機能を果す部分を層（レーヤー）と呼んで いる。それは雨水を飲料水にかえるときに，それぞれの 機能をもったろ過層を通すのに似ている。

各層の名称を Fig. 1 に示す. 理解しやすくするために 各層の機能を手紙を例にとって説明する．アプリケーシ ヨンレベルは何か伝えたいという意志を示す。

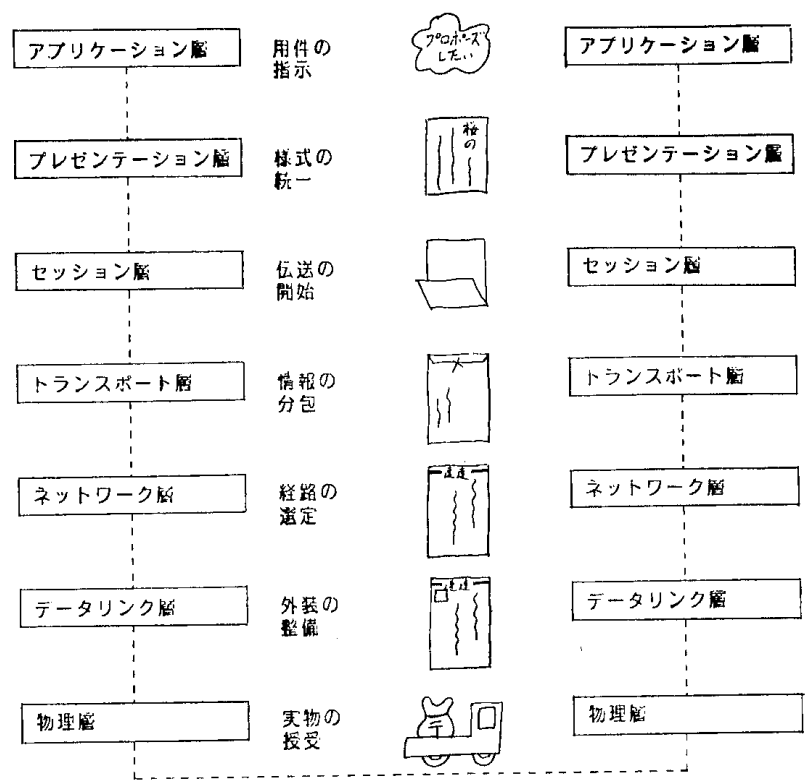

Fig. 1 ISO-OSI参照モデル

プレゼンテーション層はこの意志をきまった形式に交 換する，つまり手紙の場合は最初を前略とするか，時候 の挨拶を入れるか，箇条書きにするかなど，目的により 形式をきめることに似ている.

セッション層は，初めて手紙を送り出したときそして 最後に手紙を送るのをやめるときに書く手紙の内容に似 ている。つまり，伝送の開始，終了を制御する。それか ら正しい相手にわたすこともセッションの役目である.

トランスポート層は，手紙を封筒に入れるのに似てい る。つまり，一つの封筒に入らなければ何通かにわけた りする。また相手の宛名，自分の住所，名前を記入する ことにあたる。

ネットワーク層は，通信の経路を指定する，ちょうど， 普通郵便，書留あるいは速達を選択するのに似ている。

データリンク層は，そのまま配送できるように，重量 をはかり切手をはることにあたる。つまりデータを正確 に伝送できるように体裁をととのえる。

物理層は電気的信号のやりとりを行う. 手紙でいえば, トラックや鉄道での輸送にあたる.

このように通信機能を階層化することにより，以下の メリットが生まれる。

1)通信の機能にもれがなくなり標準化作業がやりやす くなる。

2) 各層ごとに上下層のことのみ考慮してプログラムを 作成すれ桹いので，プログラムが各層独立して作 成できる。

3) 各機器の同じ層間の通信を考慮すれば良いので通信 
のあやまりが少なくなる。

\section{ACR-NEMA デジタル画像 通信規格}

画像機器の間で画像を送受信するためのプロトコルと して ACR-NEMA ディジタル画像通信規格がある。こ れは米国の ACR (american colleague of cardiology) $と$ NEMA (national electrical manufactures association)が共同して作成したものである.1984年 1 月より作 業が開始され1985年 NEMA より NO. 300-1985として 正式にリースされた，

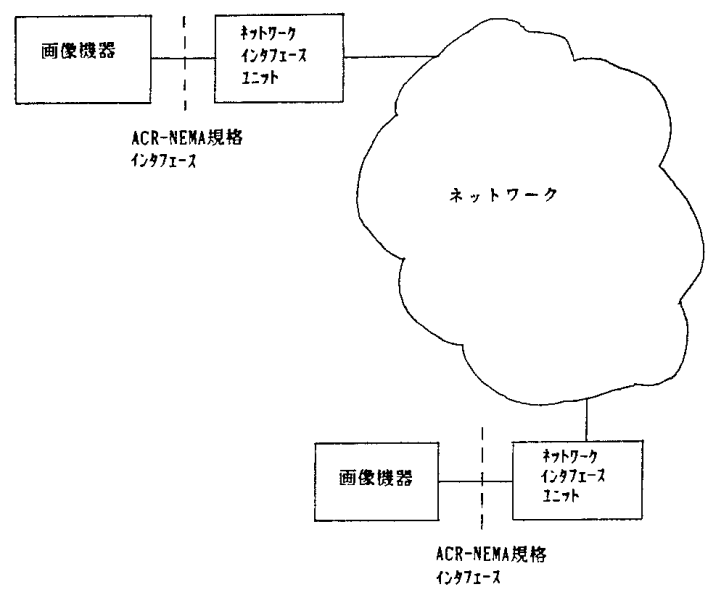

Fig. 2 ACR-NEMA規格の接続点

この規格は Fig. 2 のように，画像機器とネットワーク の間にネットワーク・インタフェース・ユニットをおく ことを仮定し, 画像機器とネットワーク・インタフェー ス・ユニット間の画像伝送プロトコルを規定している。 したがって本規格はネットワークそのものの規格ではな い. ACR-NEMA のプロトコルを各ネットワークの伝送 プロトコルに合わせてネットワーク・インタフェース・ ユニットの中で変換する。

したがってどのようなネットワークにも対応できるの で，ネットワークの進歩の激しい現在では妥当な規格と いえる。

ここでいう画像機器とは CT スキャナ等の画像収集シ ステム，画像データベースおよびワークステーションな どの画像表示装置をさす。

本規格はネットワークを介さずに直接画像機器間の画 像通信プロトコルとしても適用できる.たとえば, CT ス キャナと画像ファイリング装置を直接接続する場合にも 適用できる。

本規格は事務用の大型計算機間の通信規格として標準
化が進めつつある OSI 規格や，工業用として標準化の進 みつつある MAP とは異なっている.しかしプロトコル は前項で述べたOSI 参照モデルの各層に従って階層的 に定義されている.しかしトランスポート層とネットワ ーク層の区別はなく同一の層として定義されている。

物理層は50ピンのコネクタで，16対のデータラインと 1 対のパリティライン， 6 対の制御ライン， 1 対のグラ ンドラインからなる。電気的特性は EIA485 規格に従う 差動信号である．最高伝送速度は 8 メガ・バイト/秒で最 低速伝速度は 2 バイト/秒である。

データ・リンク層はデータを正確に伝送するために何 ワード伝送するか，今送っているものはデー夕なのかス テータスなのかを示すフレーム・ディスクリプタ・ワー ドを先頭につけ，相手側はそれを認識しデー夕の制御を 行う。またビットの愦りがなく正しく送られたかを示す フレーム・チェック・シーケンスのためのワードを最後 尾につける，このようにデータ・リンク層では，信号を フレームとして扱い，きめられた語数を伝送することを 目的としている.

トランスポート/ネットワーク層は,メッセージを2048 語以下に分割して伝送する。これは，画像機器とネット ワーク・インタフェース・ユニットの間にチャンネルを 確立するためのコードやデータかコマンドかを識別する コードをもつパケット・ディスクリプタ・ワードを先頭 にもつ．また分割されたデータが何番目のものか，最終 のものかを示すワードを 2 番目にもつ.

トランスポート/ネットワーク層により, 画像機器のパ ケットはネットワーク・インタフェース・ユニットに送 られる。ネットワーク・インタフェース・ユニットは， 使用しているネットワークのプロトコルに従って，目的 のネットワーク・インタフェース・ユニットへパケット を送り，相手のネットワーク・インタフェース・ユニッ 卜は, 相手の画像機器へ本規格のプロトコルで伝送する. これにより,相手の画像機器のトランスポート/ネットワ ーク層へパケットを伝送することができる。

セッション層は，相手の画像機器との接続開始抒よび 終了を制御する。このためには, 画像機器の論理アドレ ス名执よびネットワーク・インタフェース・ユニットの ネットワークにおけるアドレスを定義しておく必要があ る.

プレゼンテーション層は，実際のメッセージを伝送す るための形式をととのえる役目をする。メッセージはデ ータエレメントの連続した集合からなる。

画像付帯情報の各項目，たとえば患者番号，氏名など 
が各々データエレメントで表現される。

データエレメントは Fig.3に示すようにグループ番 号, エレメント番号, 数值長拉よひ数值からなり, 数值 長を定義することにより任意の長さの数值をおくること が可能である。

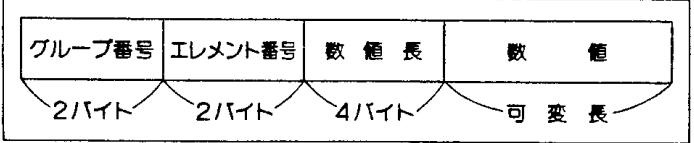

Fig. 3 データエレメントの構成

Table 1 エレメントのグループ分類

\begin{tabular}{|c|c|c|}
\hline $\begin{array}{c}\text { グル—プ番号 } \\
(\mathrm{Hex})\end{array}$ & 情報のタイプ & グループの内容の記述 \\
\hline $\begin{array}{lllll}0 & 0 & 0 & 0\end{array}$ & コマンド & 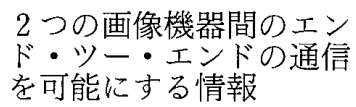 \\
\hline $\begin{array}{llll}0 & 0 & 0 & 8\end{array}$ & 同 & $\begin{array}{l}\text { ユーザへ画像を同定する } \\
\text { パラメータの情報 }\end{array}$ \\
\hline $\begin{array}{llll}0 & 0 & 1 & 0\end{array}$ & 患 & 患者に \\
\hline $\begin{array}{llll}0 & 0 & 1 & 8\end{array}$ & 収 & $\begin{array}{l}\text { 画像収集機器执よび画像 } \\
\text { 処理に関する情報 }\end{array}$ \\
\hline $\begin{array}{llll}0 & 0 & 2 & 0\end{array}$ & 関連 & $\begin{array}{l}\text { 患者部位や他の関連する } \\
\text { 画像情報 }\end{array}$ \\
\hline 0028 & 画像表示 & $\begin{array}{l}\text { 画像をもとと同じ状態あ } \\
\text { るいは再構築するための } \\
\text { 手法に関する情報 }\end{array}$ \\
\hline 40000 & テキスト & アスキー・テキスト \\
\hline 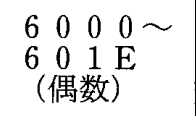 & オーバーレイ & $\begin{array}{l}\text { 画像に付属したオーバー } \\
\text { 情報画素デー夕に関する }\end{array}$ \\
\hline $7 \mathrm{FEO}$ & 画素データ & 画素データ \\
\hline
\end{tabular}

エレメントは Table 1 のようにグループ番号により項 目を大分類しエレメント番号により小分類を行っている. コマンドも付帯情報も画像データも同じメッセージ形式 で伝送する。

コマンドは, 画像を送るのか, 受信要求するのか, ま た検索をするなどの機能を指示する，コマンドに対する 応答もコマンド・レスポンスとして同じ形式で返送され る.

このように送信する場合はFig.4のようにメッセー ジがパケットになり次にフレームになる，受信する場合 はその逆である，送信の場合は，次々に何重に包装する ように各層でディスクリプタ・ワードが付加されていく. 受信の場合はタマネギの皮をはぐように，ディスクリプ タ・ワードが各層ではがされて行く.

トランスポート/ネットワーク層で見ていると,最初に

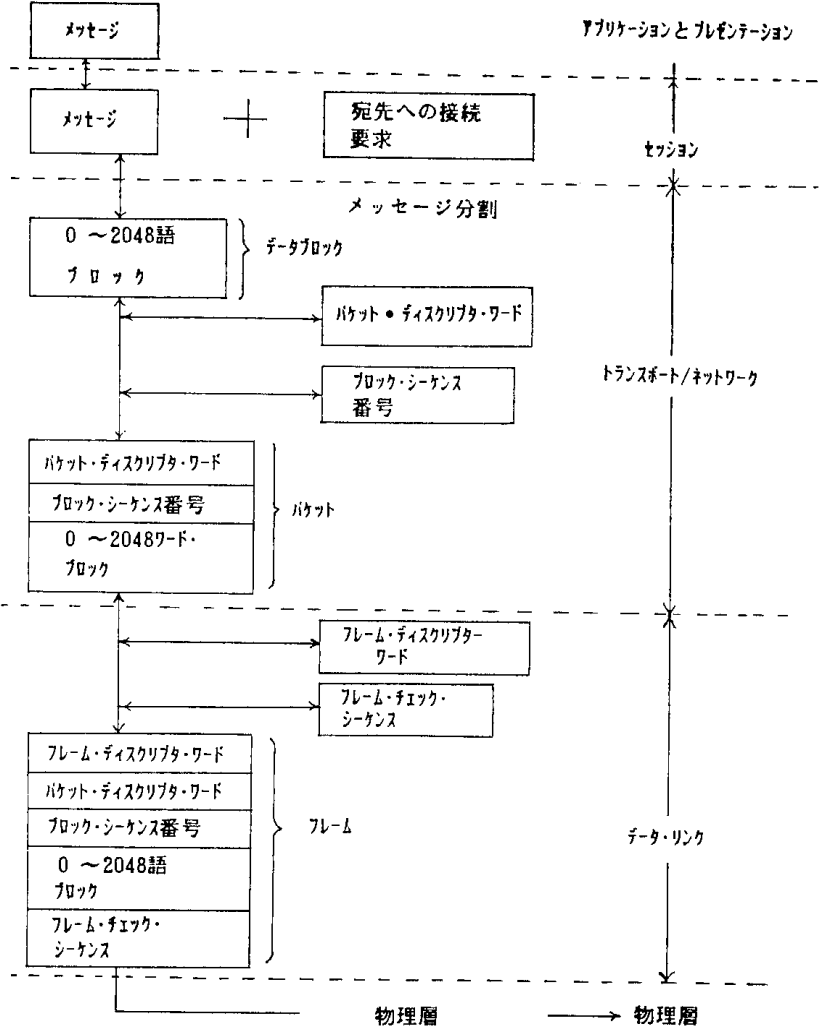

Fig. 4 ACR-NEMAの階層化

チャンネルをオープンするプロトコルのやりとりがある. 次にコマンドの送信があり，次にデータが伝送される。 次に相手画像機器よりメッセージがコマンド通り伝送さ れたかを確認するメッセージ・レスポンスがかえされる。 最後にチャンネルをクローズするプロトコルがあり一連 の伝送が終了する。

このように通信プロトコルは確実な通信を行うために 複雑な手順をとる。しかし日常ユーザに直接目にみえ関 係するのは50ピンのコネクタぐらいである。しかし PACS のシステムを設計したり運用を検討する場合は, 制約条件を把握するためにこのプロトコルを理解してお かなければならない.例えばプレゼンテーションレベル のメッセージ・フォーマットはファイル設計や画像検索 機能の制約になる。

\section{MIPS デジタル画像通信規格}

MIPSは medical imaging processing systems の略 である，通産省工業技術院の指導で MIPS 委員会が作ら れ標準化を検討している. 本委員会は1985年から1989年 までの 5 年間の予定で, 最後は標準化案のシミレーショ ンとパイロットシステムの構築を計画している.

1985年は磁気テープフォーマットの標準化案を作成し 
た. 1986年はこの実績をもとにACR-NEMA 案を参考 にして，デジタル画像通信規格案を検討している．最終 案は1987年中にまとまる予定である。

主に ACR-NEMA 案のサブセットとして位置づけ, できるだけ最低限の仕様にとどめている。しかし部位コ 一ドなど ACR-NEMA 規格では登録できないものを新 たに追加したものもある. 今後具体的システムを考慮し 最終案にまとまる予定である. MIPS 規格は日本の事情 を考慮しているので日本ではこの規格を最低要求仕様し て実現することが望ましい.

\section{5. 磁気テープフォーマット}

オンラインによる画像伝送は, ディジタル出力機能が ないと実行できない。またりフトウェアの開発量が多い ので簡単に色々な機器を接続することは現状ではむつか しい. 現状で一番互換性のあるものは依然として磁気テ ープである。

現在各メーカの磁気テープのフォーマットは, 各機器 のファイル構造を引継いでいる。したがって標準フォー マットに変換すると記録速度が落ちるのでルーチン業務 ではメーカ独自のフォーマットを採用している，磁気テ ープで画像を交換するためにはユーザの要求により標準 フォーマットが出力できることが望ましい.

現在医用磁気テープフォーマットとして提案されてい るものに JAMICフォーマット，MIPSフォーマットお よびACR-NEMA フォーマットがある．前二者は日本 のもので最後は米国のものである.

JAMICフォーマットは Fig. 5a)に示すようにヘッダ 部と画像部で一枚の画像を記録する.ヘッダ部は Fig. 5b)に示すように，6つの部分からなり，画像に付帯する 情報を示す。すなわち誰の, 何時撮影した, どんな画像 かを表している。

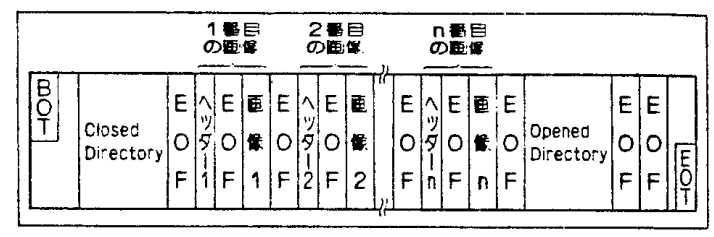

a)

フェイル谟

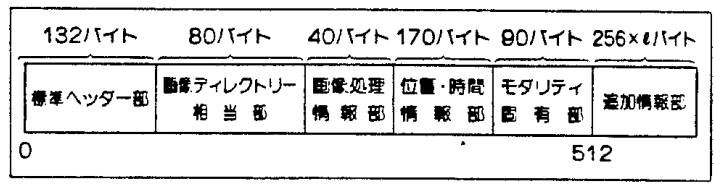

b) ヘッター暗の成

Fig. 5 JAMICフォーマットの構成

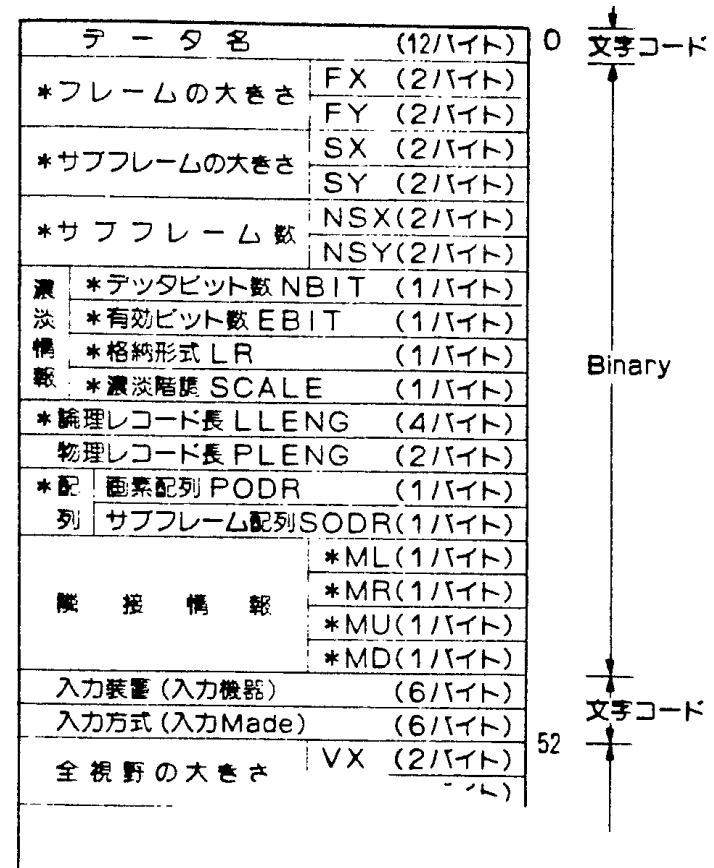

Fig. 6 JAMICフォーマットの標準ヘッダ部

標準へッダ部は Fig. 6 に示すように，画像のマトリッ クス数，1画素のビット数を示している. そのためどん なサイズの画像でも記録できる。追加情報部は, 512 バイ トで表現しきれない情報があれば追加するもので，主に 各社別の独自情報を記録する。

画像部は標準へッダに従って, 各画素のデータを順番 に記録する，再生する場合は，標準へッダに従って，配 列しなおすことにより，画像として再生する。

画像とへッダを EOFで区切って一組とする方法は情 報処理学会で制定した標準フォーマットと同じである.

また標準ヘッダ部も互換性がある.

医用としての特長は，磁気先頭にクローズドディレク トリーと最高尾にオープンディレクトリーをもうけたこ とである。その目的は，磁気テープに記録されている画 像がどの患者のものか何枚入っているかがここを読取っ ただけでわかることである。

したがってこのディレクトリー部を読みとばせば情報 処理学会の標準フォーマットを再生できるプログラムで, JAMICフォーマットの磁気テープから画像を再生する ことができる.

MIPSフォーマットは JAMICフォーマットが情報処 理学会の標準フォーマットとの互換性を保つためにわか りにくいとのことから, 最低限の付帯情報を残した. デ イレクトリーも簡単にした. ヘッダは Fig. 7a)のように 簡単になっている，撮影部位，患者体位および撮影方向 


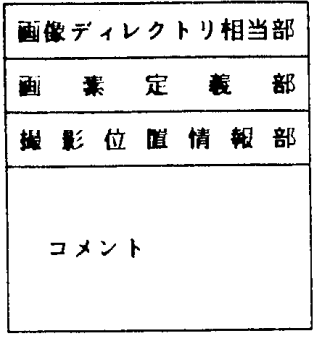

(128パイト)

( 24 バィト)

( 30 バイト)

(320バィト)

a) ヘッタの棬成

\begin{tabular}{|c|c|c|c|c|}
\hline \multirow{2}{*}{ フレームの大きき } & $\mathrm{FX}$ & (2バィト) & & \\
\hline & F Y & (2パイト) & & \\
\hline データビット数 & NB $1 \mathrm{~T}$ & $(1$ バ1ト) & & \\
\hline 有効ビット数 & E B I T & (1パ1ト) & & \\
\hline 予借 & & $(1$ パト) & & \\
\hline 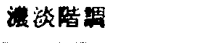 & $S C A L E$ & $(1$ バ1 & & \\
\hline \multirow{2}{*}{ ビクセル・サイズ } & $\mathrm{x}$ & $(6$ バィト) & \multirow{4}{*}{ 文 } & \\
\hline & $\mathrm{Y}$ & $(6$ パィト) & & \\
\hline \multirow{2}{*}{ ビクセル単立 } & $X U$ & (2ハイト) & & $J$ \\
\hline & $Y U$ & (2バイト) & & \\
\hline
\end{tabular}

b )

Fig. 7 MIPSフォーマットの構成

は記号で表現できる。

画素の定義もFig. 7b)に示すように簡略化されている. ただし，ピクセル単位でX軸，Y軸の両方が定義できる。 これにより超音波のMモードのようにX軸に時間， $\mathrm{Y}$ 軸 に距離のような画像も記録可能となった。

JAMIC フォーマットはディレクトリー部が追加可能 であるので, 画像の生成ごとに 1 枚ずつ記録していくこ とができる.一方, MIPSフォーマットは, ディレクトリ 一の追加ができないので，磁気ディスクから一度に磁気 テープにコピーする方式である。

ACR-NEMA フォーマットは, ディジタル画像通信規 格と同様に画像の付帯情報を示すへッダ部は可変長のデ ータを記録できる。ディレクトリー部分は固定長で思想 に一貫性がない部分もある。

JAMICフォーマットは, 日本放射線機器工業会が主 要メンバとしてまとめたため JIRA フォーマットとも呼

ばれ，CR 装置などに基本部分が応用されている。

機器固有の磁気テープフォーマットが公開できない場 合は，その目的に合わせ，JAMICフォーマットあるいは MIPSフォーマットを使用するとよい.

\section{6. 標準化によりマルチベンダシステム の構築は可能か}

マルチベンダシステムを構築するために, 異なるメー カの機器間のインタフェースを標準化することが最小限 必要である.しかし現状の診断機器はPACS を意識して いないために，外部へ画像を出力する場合，いくつかの 制約をもっている。これがマルチベンダシステムの構築 の際のシステム設計での制約条件になり，画像機器を機 能的にランク分けする必要がある。

例えば CT スキャナを例にとると ID 番号，氏名や付 帯情報を入力するのに手間がかかるので，単なるシーケ ンス番号で管理している施設が多い.また撮影条件, 部 位コードも機器のプログラム上出力できる構造になって いない機器が多い.

こうした画像の同定と付帯情報の入力に関して, 診断 機器から直接画像に付属して出力できる場合と RISや HIS などの他の情報管理機器の助けを貸りる必要があ る場合とが考えられる。

それに加え，診断機器は計算機の性能の限度まで画像 の再構成能力や画像ファイリングの能力を高めているた めに通信機能にわりあてる時間的余裕を持っていない機 器が多い. 現状では撮影をしていない昼休みか, 時間外 に画像を伝送するのが普通の機器の能力である。したが って今後, PACS 接統用の診断機器が開発されるべきで ある，その際でも，画像を再構成後すぐデータベース側 へ伝送するのか，まとめておくるのか，データベースの 要求によって伝送するのか, すべての機能を持つ必要が あるかによって診断機器側の開発コストも変わってくる。

また ACR-NEMA 規格にしろ，それを日本版にした MIPS 規格にしろ最低限の規格である．特にデータベー ス検索機能は十分とはいえない．また画像付帯情報は可 変長のため固定領域に表示する場合十分な情報が表示で きるとはかぎらない. その上各メ一力独自の情報も付加 できるので附帯情報は色々なバラエティーに富んだもの になる。

以上のような 3 点，すなわち，画像の同定と附帯情報 の入力, 画像の伝送のタイミングおよび ACR-NEMA 規格への追加による多椂性によってもシステム構築の方 法が異なってくる，各メーカがシステムに独自性を出す ためには, 自メーカ機器間は独自プロトコルで行い他社 間は標準プロトコルで行うのが能率的かもしれない。

PACS を構築する場合, システム設計責任者がいて， 各メーカへこうした点を考慮した仕様を出す形が望まし 
い. 単に, 標準インタフェース仕様のみをもった機器を 注文してつなぎ合わせても，画像はいつか伝送されてく るだろうが，とても運用上耐えられないものになる可能 性が十分ある。

それにしても，インタフェースの標準化案の制定は PACS の第一歩であることは間違いない. 今後, MIPS 委員会では MIPS 規格の具体化方法のガイドラインの 検討，規格適合試験の検討を計画している。この活動を 通じ，各メーカが歩みより標準化されたインタフェース が実現され，マルチベンダシステムが可能になることを 期待している.

\section{文献}

1) $\mathrm{ACR}-\mathrm{NEMA}$ : Digital Imaging and Communications. ACR-NEMA STANDARDS PUBLICATION/NO. 300-1985.

2) 医用画像処理システム委員会：ACR-NEMA ディ ジタル画像と通信規格. 日本放射線工業会, (1986).

3)「医用機器関連工業会連絡会の設置及び運営」報告 書. 日本放射線機器工業会, p. $10 \sim 20$, 昭和 58 年 4 月.

4）「医用画像処理システムの標準化に関する調査研究」 委託成果報告書. 日本放射線機器工業会, p. 28 $\sim 42$, 昭和 61 年 4 月. 